\title{
ANALYSIS OF SAGITTAL BALANCE AND SPINOPELVIC PARAMETERS IN A BRAZILIAN POPULATION SAMPLE
}

\author{
ANÁLISE DOS PARÂMETROS DO EQUILÍBRIO SAGITAL E ESPINO-PÉLVICO \\ EM UMA AMOSTRA POPULACIONAL BRASILEIRA
}

\author{
ANÁLISIS DE LOS PARÁMETROS DEL EQUILIBRIO SAGITAL Y ESPINOPÉLVICO \\ EN MUESTRA DE POBLACIÓN BRASILEÑA
}

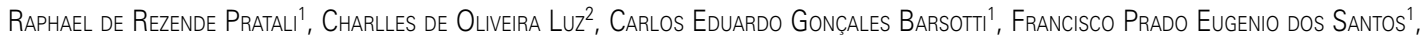
Carlos Eduardo Algaves Soares de Oliveira ${ }^{3}$

\begin{abstract}
Objective: To define the sagittal balance and spinopelvic parameters in a Brazilian population sample composed of asymptomatic volunteers Methods: Fifty healthy adult individuals volunteered to participate in this study. The exclusion criteria included spinal deformity or improper radiograph study. In each radiograph exam in profile view, the sagittal balance and spinopelvic parameters were evaluated, including vertical sagittal axis, sacral slope, pelvic tilt and pelvic incidence. Results: The data obtained in this study are according to the values presented in the worldwide literature. None of the radiographic parameters showed any differences between the genders. Comparing the values presented in this study with those of other reports, with different populations, it was observed that: there was no significant difference in any of the pelvic parameters between Brazilian and Korean populations; there was a significant difference in pelvic incidence between Brazilian and European populations in a total sample $(p=0.0001)$, in males $(p=0.02)$, and in females $(p=0.0007)$; there was a difference in sacral slope between Brazilian and European populations in a total sample $(p=0.0140)$, and in females $(p=0.005)$. Conclusion: There were no differences in any parameter in terms of gender. There were no differences in pelvic incidence between Brazilian and Korean populations. There was a difference in pelvic incidence between Brazilian and European populations, in the total sample and in males and females. There was a difference in sacral slope between Brazilian and European populations in a total sample, and in females.
\end{abstract}

Keywords: Pelvis; Lordosis; Population groups; Radiography.

\section{RESUMO}

Objetivo: Definir os parâmetros do equilíbrio sagital e espinopélvico numa amostra da população brasileira composta por indivíduos voluntários assintomáticos. Métodos: Cinquenta indivíduos adultos saudáveis foram voluntários a participar do estudo. Os critérios de exclusão foram deformidade da coluna vertebral ou exame de imagem inadequado. Em cada radiografia na incidência de perfil, foram analisados os parâmetros do alinhamento sagital e espinopélvico, incluindo o eixo sagital vertical, a inclinação sacral, a versão pélvica e a incidência pélvica. Resultados: Os valores obtidos na amostra do estudo estão de acordo com os valores descritos como normais na literatura mundial. Não houve diferença em nenhum dos parâmetros radiográficos com relação ao sexo dos indivíduos. Os valores obtidos no estudo, comparados com valores de outras populações publicados na literatura, permitem obsenvar que: não houve diferença significativa em nenhum parâmetro pélvico entre a população brasileira e a coreana; houve diferença significativa na incidência pélvica entre a população brasileira e a europeia na amostra total $(p=0,0001)$, no sexo masculino ( $p=0,02)$ e no sexo feminino ( $p=0,0007)$; houve diferença na inclinação sacral entre a população brasileira e a europeia na amostra total $(p=0,0140)$ e no sexo feminino $(p=0,005)$. Conclusões: Não houve diferença em nenhum parâmetro quanto ao sexo dos indivíduos. Não houve diferença em nenhum parâmetro entre a população brasileira e a coreana. Houve diferença na incidência pélvica entre a população europeia e brasileira, quanto na amostra total e aos sexos masculino e feminino. Houve diferença na inclinação sacral entre a população europeia e brasileira, quanto à amostra total e ao sexo feminino.

Descritores: Pelve; Lordose; Grupos Populacionais; Radiografia.

\section{RESUMEN}

Objetivo: Definir los parámetros de equilibrio sagital y espinopélvico en una muestra de la población brasileña compuesta por voluntarios asintomáticos. Métodos: Cincuenta individuos sanos fueron voluntarios para participar en el estudio. Los criterios de exclusión fueron deformidad espinal o exámenes de imagen inapropiados. En cada radiografía lateral, se analizaron los parámetros de alineamiento sagital y espinopélvico, incluyendo el eje sagital vertical, la inclinación del sacro, la versión pélvica y la incidencia pélvica. Resultados: Los valores obtenidos en la muestra del estudio son consistentes con los valores descritos como normales en la literatura mundial. No hubo diferencias en ninguno de los parámetros radiográficos con respecto al sexo de los individuos. Os valores obtenidos en el estudio, en comparación con valores de otras poblaciones reportados en la literatura, nos permiten observar que no había diferencia significativa en ningún parámetro pélvico entre la población brasileña y la coreana; había diferencia significativa en la incidencia pélvica entre la población brasileña y la europea en la muestra total $(p=0,0001)$ en los varones $(p=0,02)$ y en mujeres $(p=0,0007)$; hubo diferencia en la inclinación del sacro entre la población brasileña y la europea en la muestra total ( $p=0,0140$ ) y en mujeres $(p=0,005)$. Conclusiones: No hubo diferencias en ningún parámetro cuanto al sexo de los individuos. No hubo diferencia en ningún parámetro entre la población brasileña y la coreana. Hubo diferencias en la incidencia de la pelvis entre la población europea y la brasileña en la muestra total, tanto en varones cuanto en mujeres. Hubo diferencia en la inclinación del sacro entre la población europea y la brasileña en la muestra total y en el sexo femenino.

Descriptores: Pelvis; Lordosis; Grupos de población; Radiografía.

1. Spine Surgery Group of the Hospital do Servidor Público Estadual - São Paulo, SP, Brazil. 


\section{INTRODUCTION}

The vertebral spine plays an important role in the support and locomotion of the human body. An understanding of the elements that compose it is essential for learning about its role in body balance and alignment. ${ }^{1-4}$

Thoracic kyphosis and lumbar lordosis measurements are used to analyze trunk alignment. Overall vertebral alignment is assessed by the plumb line method. ${ }^{1-4}$ More recently, the role of the pelvis has been widely recognized in the evaluation of spinal balance and alignment ${ }^{5-7}$, with the introduction of the concepts of Pelvic Incidence (PI), Pelvic Tilt (PT), and Sacral Slope (SS).

Deformities of the sagittal plane, such as loss of lumbar lordosis, can cause anterior inclination of the trunk, affecting sagittal balance. The main causes of loss of sagittal balance are degenerative diseases, inadequate fixation of the lumbar spine, post-traumatic deformity, and ankylosing spondylitis. In the initial stages of deformity, retroversion of the pelvis may compensate for the loss of sagittal balance, but with the progression of degenerative changes, its capacity to accommodate the trunk is exceeded, associated with an increase in the energy expended to maintain erect posture, causing pain, fatigue, and functional disability. ${ }^{7,8}$

To analyze the consequences of changes in sagittal balance in each individual, we need to understand the normal parameters for the population. Several studies ${ }^{6-12}$ have evaluated the relationship between the position of the pelvis and spinal alignment. However, it is important to know the values of these radiographic parameters in healthy individuals, without spinal disease. Although some studies address these parameters, it is interesting to evaluate them in a specific population as there are structural differences between different population groups. We identified publications with evaluations of individuals from the European, ${ }^{13}$ Causcasian, ${ }^{14}$ and Korean ${ }^{15}$ populations. However, a similar study has not yet been conducted for the Brazilian population.

The objective of this study is to observe the parameters of sagittal and spinopelvic balance in a sample of the Brazilian population consisting of volunteer asymptomatic individuals, in order to establish the relationship between these parameters, age, and sex and to compare the results with those of other studies that cover other population groups.

\section{METHODS}

The group analyzed comprised 50 adults who volunteered to take part in the study, including doctors and employees of the hospital where the study was carried out. All the individuals were Brazilian, over 20 years of age, and had no history of spinal pain or disease. Exclusion criteria included the presence of spinal deformity or inadequate imaging exams that would prevent proper analysis of the parameters in question.

Panoramic radiographs of the spine were performed in frontal and profile views in the orthostatic position. All were performed at the same radiology department, by the same professional, using the same technique. The exams were obtained with the individuals in a standing position with the knees extended and the hands on the supraclavicular fossae. ${ }^{16}$ Long cassettes $(91 \mathrm{~cm})$ were used and the radiograph was centered on T12 in inspiration, with a distance of 2 meters between the film and the focus. The images were digitalized and evaluated using Surgimap Spine software (Nemaris Inc., New York, USA). (Figure 1)

The sagittal and spinopelvic alignment parameters analyzed were sagittal vertical axis (SVA), sacral slope (SS), pelvic tilt (PT), and pelvic incidence (PI). (Figures 2 and 3)

All the parameter values studied were statistically analyzed. The statistical analysis was based on calculations of the average value, the standard deviation, and the standard error of both the data from the sample and those obtained from the published studies of different populations. The comparisons between groups were performed using the Student's t-test. The level of significance used was $5 \%$.

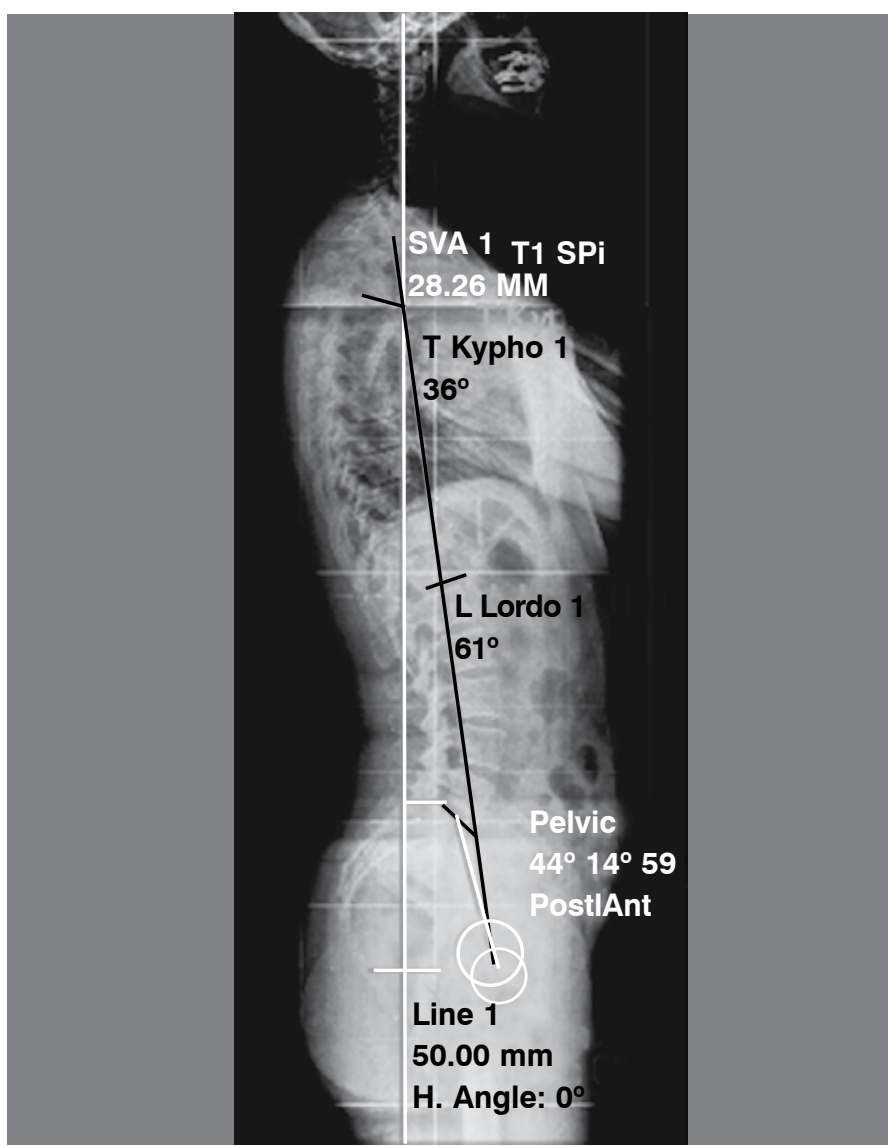

Figure 1. Measurements of the radiographic parameters of interest in a digitalized image using Surgimap Spine software (Nemaris Inc., New York, USA).

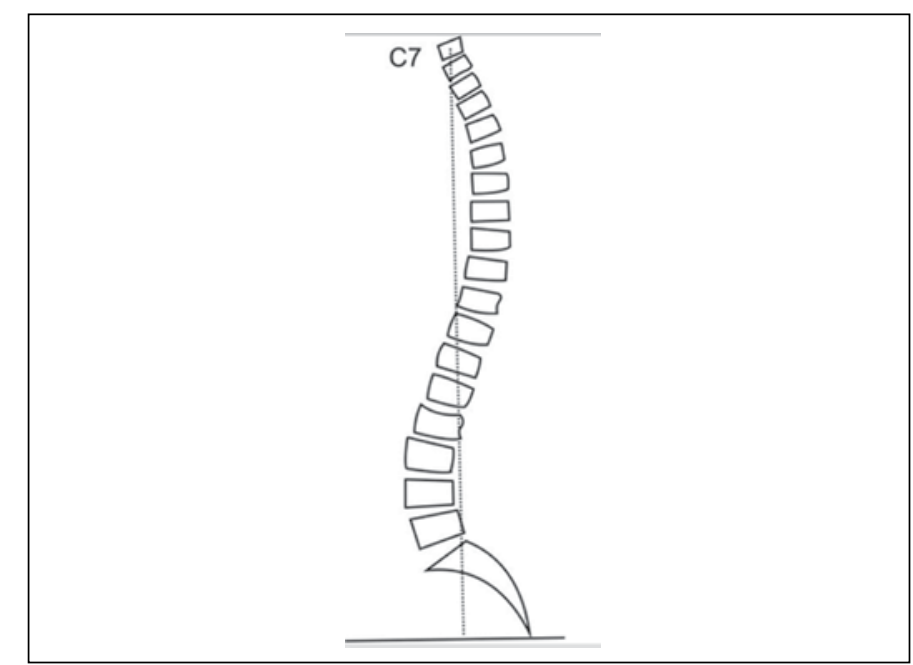

Figure 2. The sagittal vertical axis, corresponding to the "plumb line" in the sagittal plane, is measured as the distance between the line originating in the center of the body of $\mathrm{C} 7$ and the posterior-superior corner of the sacrum.

\section{RESULTS}

Of the 50 volunteers analyzed, 25 were male and 25 were female. The average age of the volunteers was 34.85 years, ranging from 22 to 50 years of age. The average age of the male volunteers was 32.3, while the average age of the female volunteers was 37.4.

Table 1 displays the averages and standard deviations of the pelvic incidence, sacral slope, pelvic tilt, and sagittal vertical axis of the sample. Table 2 displays the normal values reported in other studies of different populations. . $^{11,13,17,18}$ 


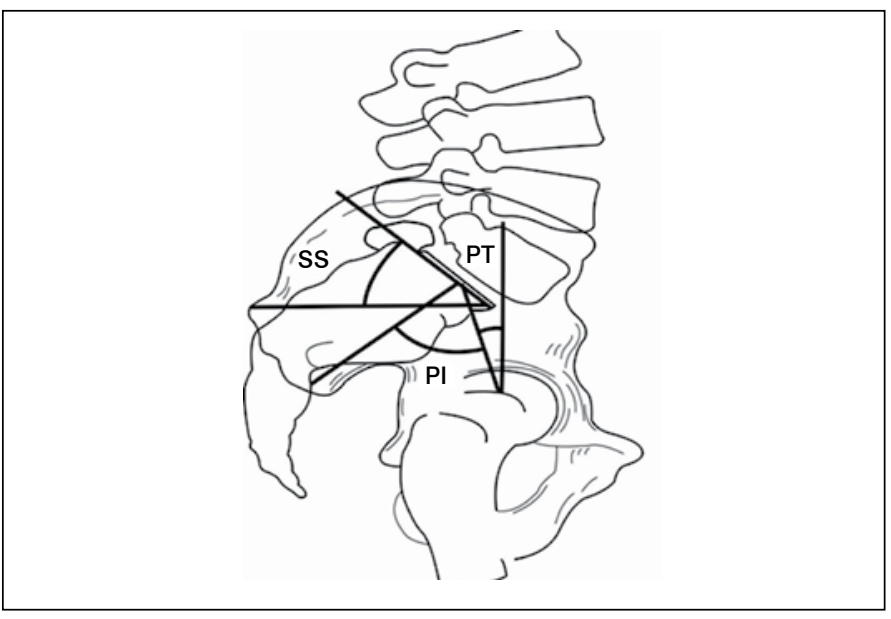

Figure 3. Measurement of the angles of pelvic incidence (PI), pelvic tilt (PT), and sacral slope (SS).

There were no differences observed between males and females for any of the pelvic parameters in the population studied. (Table 3)

A comparison between the pelvic parameter values of the individuals in our study and the values reported for the European and Korean populations is shown in Table 4, with no difference noted between the Brazilian and Korean populations. However, differences between the European population and the Brazilian population sample were observed in relation to pelvic incidence and sacral slope $(p=0.0001$ and $p=0.0140)$, with higher values for both parameters in the European population.

The averages and standard deviations of the pelvic parameters for males of all three population groups and the descriptive values (p) for the comparison between Europe and Brazil $\left(p^{1}\right)$ and between Korea and Brazil $\left(\mathrm{p}^{2}\right)$ are presented in Table 5. We observed that there was no difference between any of the parameter values for the Brazilian and Korean populations. However, there was a difference between the pelvic incidence values of the Brazilian and European populations $(p=0.02)$, with higher values in the European population.

The averages and standard deviations of the pelvic parameters for females of all three population groups, and the descriptive values $(p)$ for the comparison between Europe and Brazil $\left(\mathrm{P}^{1}\right)$ and between Korea and Brazil $\left(\mathrm{P}^{2}\right)$ are shown in Table 6. We can see that there was no difference between any of the parameter values for the Brazilian and Korean populations. However, there were differences between the pelvic incidence and sacral slope values of the Brazilian and European populations $(p=0.0007$ and $p=0.005)$. Both the pelvic incidence and sacral slope values of the European population were higher than those of the Brazilian population.

Table 1. Values for total, male, and female volunteers

\begin{tabular}{c|c|c|c|c|c|c}
\hline & \multicolumn{2}{|c|}{ Total } & \multicolumn{2}{c|}{ Male } & \multicolumn{2}{c}{ Female } \\
\cline { 2 - 7 } & Average & SD & Average & SD & Average & SD \\
\hline Pelvic incidence $\left(^{\circ}\right)$ & 48.7 & 9.6 & 49.1 & 6.4 & 48.3 & 9.6 \\
\hline Sacral slope $\left(^{\circ}\right)$ & 38 & 8.4 & 38.2 & 6.9 & 37.8 & 8.4 \\
\hline Pelvic tilt $\left(^{\circ}\right)$ & 12.15 & 6.2 & 12.1 & 6.2 & 12.2 & 5.3 \\
\hline SVA $(\mathrm{cm})$ & -1.735 & 3.7 & 1.93 & 3.2 & -1.54 & 3.6 \\
\hline \multicolumn{5}{|c|}{} \\
\hline
\end{tabular}

Table 2. Normal values in the general literature. $11,13,16,17$

\begin{tabular}{c|c}
\hline Parameters & Degrees \\
\hline Pelvic incidence & $40-65$ \\
\hline Sacral slope & $30-50$ \\
\hline Pelvic tilt & $10-25$ \\
\hline SVA & $0.5 \mathrm{~cm}( \pm 2.5 \mathrm{~cm})$ \\
\hline
\end{tabular}

Table 3. Comparison between volunteers by sex.

\begin{tabular}{c|c|c|c|c|c}
\hline & \multicolumn{2}{|c|}{ Male (n=25) } & \multicolumn{2}{c|}{ Female (n=25) } & \multirow{2}{*}{ p-value } \\
\cline { 2 - 5 } & Average & SD & Average & SD & \\
\hline Pelvic incidence $\left(^{\circ}\right)$ & 49.1 & 6.4 & 48.3 & 9.6 & 0.7306 \\
\hline Sacral slope $\left(^{\circ}\right)$ & 38.2 & 6.9 & 37.8 & 8.4 & 0.8548 \\
\hline Pelvic tilt $\left(^{\circ}\right)$ & 12.1 & 6.2 & 12.2 & 5.3 & 0.9514 \\
\hline
\end{tabular}

Table 4. Comparison between total values.

\begin{tabular}{|c|c|c|c|c|c|c|c|c|}
\hline & \multicolumn{8}{|c|}{ Total } \\
\hline & \multicolumn{2}{|c|}{ Brazil $(n=50)$} & \multicolumn{2}{|c|}{ Europe $(n=300)$} & \multicolumn{2}{|c|}{ Korea $(n=86)$} & \multirow{2}{*}{$P_{1}$} & \multirow{2}{*}{$\mathbf{P}^{2}$} \\
\hline & Average & SD & Average & SD & Average & SD & & \\
\hline Pelvic incidence $\left({ }^{\circ}\right)$ & 48.7 & 9.6 & 54.7 & 10.6 & 47.8 & 9.5 & 0.0001 & 0.5965 \\
\hline Sacral slope $\left({ }^{\circ}\right)$ & 38 & 8.4 & 41.2 & 8.5 & 36.3 & 8.6 & 0.0140 & 0.2643 \\
\hline Pelvic tilt $\left({ }^{\circ}\right)$ & 12.15 & 6.2 & 13.2 & 6 & 11.5 & 5.4 & 0.2550 & 0.5384 \\
\hline
\end{tabular}

NB: $p^{1}$ refers to the comparison between Brazil and Europe; $p^{2}$ refers to the comparison between Brazil and Korea.

Table 5. Comparison between male populations

\begin{tabular}{c|c|c|c|c|c|c|c|c}
\hline & \multicolumn{7}{|c}{ Male } & \\
\cline { 2 - 9 } & Brazil (n=25) & Europe (n=110) & Korea (n=54) & \multirow{2}{*}{$\mathbf{P}^{1}$} & \multirow{2}{*}{$\mathbf{P}^{2}$} \\
\cline { 2 - 9 } & Average & SD & Average & SD & Average & SD & & \\
\hline Pelvic incidence $\left({ }^{\circ}\right)$ & 49.1 & 6.4 & 53 & 10.6 & 48.8 & 7.3 & 0.0200 & 0.8538 \\
\hline Sacral slope $\left(^{\circ}\right)$ & 38.2 & 6.9 & 41 & 8.5 & 37.3 & 7.1 & 0.0874 & 0.5956 \\
\hline Pelvic tilt $\left({ }^{\circ}\right)$ & 12.1 & 6.2 & 13 & 6 & 11.4 & 5.4 & 0.5142 & 0.6298 \\
\hline
\end{tabular}

Table 6. Comparison between female populations.

\begin{tabular}{c|c|c|c|c|c|c|c|c|c}
\hline & \multicolumn{7}{|c}{ Female } & \multirow{2}{*}{$\mathbf{P}^{2}$} & \multirow{2}{*}{$\mathbf{P}^{2}$} \\
\cline { 2 - 9 } & Brazil (n=25) & Europe (n=190) & \multicolumn{1}{|c|}{ Korea (n=32) } & \\
\cline { 2 - 9 } & Average & SD & Average & SD & Average & SD & & \\
\hline Pelvic incidence $\left(^{\circ}\right)$ & 48.3 & 9.6 & 56 & 10 & 46.1 & 9.5 & 0.0007 & 0.3924 \\
\hline Sacral slope $\left(^{\circ}\right)$ & 37.8 & 8.4 & 43.2 & 8.4 & 34.4 & 8.6 & 0.0050 & 0.1395 \\
\hline Pelvic tilt $\left({ }^{\circ}\right)$ & 12.2 & 5.3 & 13.6 & 6 & 11.6 & 5.1 & 0.2305 & 0.6682 \\
\hline
\end{tabular}

\section{DISCUSSION}

The overall sagittal alignment of the trunk can be measured using the sagittal vertical axis, which corresponds to the "plumb line". 1,2 It has been reported that normal adult sagittal alignment falls within a narrow margin in the pelvis, with an average sagittal vertical axis value in asymptomatic adults described as $0.5 \mathrm{~cm}$ $( \pm 2.5 \mathrm{~cm})$ from the posterior-superior corner of the sacrum. ${ }^{3}$ Since the work of Legaye and Duval-Beaupere, ${ }^{7}$ various studies have stressed the importance of the pelvis in the sagittal alignment of adults. An analysis of the pelvis in the sagittal plane is obtained by measuring three angles: pelvic incidence ( $\mathrm{Pl})$, pelvic tilt (PT), and sacral slope (SS).

The impact of loss of sagittal balance on quality of life indicators was demonstrated by Glassman et al. ${ }^{19}$ Both patients who had previously undergone spinal arthrodesis and those without any prior surgeries had poorer quality of life parameters, including the Oswestry Index, the SF-12, and the SRS-22, associated with an increase in the values of the sagittal vertical axis, which indicates a loss of sagittal balance. This study demonstrates the importance of analyzing sagittal balance both in the evaluation of patients with complaints of back pain and functional limitations and for the outcome of surgical treatment.

More recently, the correlation between the pelvic parameter PT and the worsening of quality of life parameters (Oswestry Index, SF12, and SRS-22) was demonstrated, confirming that pelvic position is correlated with impaired functional capacity in patients. ${ }^{20}$ High values of pelvic tilt indicate pelvic retroversion, compensating for the loss of sagittal balance.

However, for us to correctly understand the effects of the loss 
of sagittal balance on the quality of life of each individual, we must know the normal values of the parameters used to evaluate sagittal and spinopelvic balance in the population. Although Brazil is a country of continental proportions and a mixed population, this study presents the results of an analysis of a small sample of healthy individuals. It can be noticed that the values obtained from the sample are within the values described as normal in the literature. ${ }^{11,13,17,18}$ In our study, there were no differences in the radiographic parameters when compared by sex of the individuals evaluated.

When we compare the average values and standard deviations obtained in this study with those published in the literature for European and Korean populations, we can see that: there were no differences for any of the pelvic parameters between the Brazilian and Korean populations, even when compared by sex; the values of pelvic incidence of the European population were higher than those of the Brazilian population sample, both for the total sample and in the comparison by sex; the values of sacral slope of the European population were higher than those of the Brazilian population sample, both for the total population and for the female group; and the pelvic tilt values of the European population were similar to those obtained for the sample population studied. These data show the importance of studies in this format, aimed at adjusting the radiographic parameters for different populations.

\section{CONCLUSIONS}

This study presents the pelvic incidence, sacral slope, pelvic tilt, and sagittal vertical axis values of a sample of the Brazilian population. There were no differences in any radiographic parameter between males and females in the sample. The values obtained are compatible with the values presented as normal in the literature. A comparison of the study results with data published about other populations revealed no differences in any of the pelvic parameters between the Brazilian and Korean populations. There were differences in pelvic incidence between the Brazilian and European populations both in the total sample and in the male and female groups. There were differences in sacral slope between the Brazilian and European populations in relation to the total sample and the female group.

All authors declare no potential conflict of interest concerning this article.

\section{REFERENCES}

1. Gelb DE, Lenke LG, Bridwell KH, Blanke K, McEnery KW. An analysis of sagittal spinal alignment in 100 asymptomatic middle and older aged volunteers. Spine (Phila Pa 1976). 1995;20(12):1351-8.

2. Hammerberg EM, Wood KB. Sagittal profile of the elderly. J Spinal Disord Tech. 2003;16(1):44-50.

3. Jackson RP, McManus AC. Radiographic analysis of sagittal plane alignment and balance in standing volunteers and patients with low back pain matched for age,sex, and size. A prospective controlled clinical study. Spine (Phila Pa 1976).1994:19(14):1611-8.

4. McLean IP, Gillan MG, Ross JC, Aspden RM, Porter RW. A comparison of methods for measuring trunk list. A simple plumbline is the best. Spine (Phila Pa 1976). 1996:21(14):1667-70.

5. During J, Goudfrooij H, Keessen W, Beeker TW, Crowe A. Toward standards for posture. Postural characteristics of the lower back system in normal and pathologic conditions. Spine (Phila Pa 1976). 1985;10(1):83-7.

6. Jackson RP, Peterson MD, McManus AC, Hales C. Compensatory spinopelvic balance over the hip axis and better reliability in measuring lordosis to the pelvic radius on standing lateral radiographs of adult volunteers and patients. Spine (Phila Pa 1976). 1998:23(16):1750-67.

7. Legaye J, Duval-Beaupère G, Hecquet J, Marty C. Pelvic incidence: a fundamental pelvic parameter for three-dimensional regulation of spinal sagittal curves. Eur Spine J. 1998:7(2):99-103

8. Vaz G, Roussouly P, Berthonnaud E, Dimnet J. Sagittal morphology and equilibrium of pelvis and spine. Eur Spine J. 2002;11(1):80-7.

9. Labelle H, Roussouly P, Berthonnaud E, Dimnet J, O'Brien M. The importance of spino-pelvic balance in L5-s1 developmental spondylolisthesis: a review of pertinent radiologic measurements. Spine (Phila Pa 1976). 2005;30(Suppl 6):S27-34.

10. Legaye J, Duval-Beaupère G. Sagittal plane alignment of the spine and gravity: a radiolo- gical and clinical evaluation. Acta Orthop Belg. 2005:71(2):213-20.

11. Roussouly P, Gollogly S, Berthonnaud E, Dimnet J. Classification of the normal variation in the sagittal alignment of the human lumbar spine and pelvis in the standing position. Spine (Phila Pa 1976). 2005;30(3):346-53.

12. Schwab F, Lafage V, Boyce R, Skalli W, Farcy JP. Gravity line analysis in adult volunteers: age-related correlation with spinal parameters, pelvic parameters, and foot position. Spine (Phila Pa 1976). 2006;31(25):E959-67.

13. Vialle R, Levassor N, Rillardon L, Templier A, Skalli W, Guigui P. Radiographic analysis of the sagittal alignment and balance of the spine in asymptomatic subjects. J Bone Joint Surg Am. 2005;87(2):260-7.

14. Mac-Thiong JM, Roussouly P, Berthonnaud E, Guigui P. Sagittal parameters of global spinal balance: normative values from a prospective cohort of seven hundred nine Caucasian asymptomatic adults. Spine (Phila Pa 1976). 2010;35(22):E1193-8.

15. Lee CS, Chung SS, Kang KC, Park SJ, Shin SK. Normal patterns of sagittal alignment of the spine in young adults radiological analysis in a Korean population. Spine (Phila Pa 1976). 2011;36(25):E1648-54.

16. Marks MC, Stanford CF, Mahar AT, Newton PO. Standing lateral radiographic positioning does not represent customary standing balance. Spine (Phila Pa 1976). 2003:28(11):1176-82.

17. Barrey C, Jund J, Noseda O, Roussouly P. Sagittal balance of the pelvis-spine complex and lumbar degenerative diseases. A comparative study about 85 cases. Eur Spine J. 2007:16(9):1459-67.

18. Glassman SD, Berven S, Bridwell K, Horton W, Dimar JR. Correlation of radiographic parameters and clinical symptoms in adult scoliosis. Spine (Phila $\mathrm{Pa}$ 1976). 2005;30(6):682-8.

19. Lafage V, Schwab F, Patel A, Hawkinson N, Farcy JP. Pelvic tilt and truncal inclination: two key radiographic parameters in the setting of adults with spinal deformity. Spine (Phila Pa 1976). 2009;34(17):E599-606. 